\title{
KANDUNGAN FLAVONOID EKSTRAK METANOL DAN EKSTRAK ETIL ASETAT DAUN SUKUN (Artocarpus altilis (Park.) Fosberg) DAN AKTIVITASNYA TERHADAP PENURUNAN KADAR GLUKOSA SECARA IN VITRO
}

\author{
Sri Wardatun, Ike Yulia, Aditya Aprizayansyah \\ Program Studi Farmasi, FMIPA, Universitas Pakuan \\ Email:sri.wardatun@unpak.ac.id
}

\begin{abstract}
ABSTRAK
Daun dan kulit pohon sukun atau Artocarpus altilis (Park.) Fosberg dikenal oleh masyarakat di beberapa daerah sebagai bahan obat untuk mengobati penyakit diabetes secara alami. Hasil-hasil penelitian menunjukan bahwa daun dan kulit pohon sukun mengandung senyawa-senyawa golongan flavonoid yang tinggi, yang diyakini mampu menurunkan kadar glukosa dalam darah sehingga dapat dikembangkan sebagai obat antidiabetes. Penelitian ini bertujuan untuk mengetahui aktivitas ekstrak daun sukun terhadap penurunan kadar glukosa dan korelasinya dengan kandungan flavonoid. Kadar glukosa diukur secara in vitro menggunakan metode Nelson Somogyi dengan acuan nilai penurunan 50\% kadar glukosa baku. Ekstraksi daun sukun dilakukan dengan cara maserasi bertingkat menggunakan pelarut non polar ( $n$-heksan), semi polar (etilasetat) dan polar (metanol). Penentuan kadar flavonoid dilakukan secara spektrofotometri pada panjang gelombang $430 \mathrm{~nm}$ natrium asetat dan alumunium klorida $\left(\mathrm{AlCl}_{3}\right)$. Hasil penelitian menunjukan kadar flavonoid total ekstrak etil asetat dan ekstrak metanol adalah masing-masing sebesar $0.5554 \%$ dan $0.3727 \%$ berat sampel. Penurunan $50 \%$ kadar gukosa terjadi pada perlakuan 36.1114 ppm ekstrak etil asetat dan 39,448 ppm ekstrak metanol. Hasil uji korelasi menunjukkan bahwa ada hubungan yang nyata antara penurunan kadar glukosa dengan kadar flavonoid.
\end{abstract}

Kata kunci: Diabetes mellitus, kadar gula darah, flavonoid, sirsak, Artocarpus altilis

\section{THE ACTIVITY OF Artocarpus altilis (Park.) Fosberg LEAF EXTRACT TO DECREASE THE THE GLUCOSE LEVEL IN VITRO AND IT'S CORRELATION TO THE FLAVONOID CONTENT}

\begin{abstract}
The bark and leaf of bread fruit tree (Artocarpus altilis (Park.) have long been used as a natural antidiabetic medicinal preparations in a many regions of Indonesia. According to the recent studies, flavonoids group found to be most abundant compounds in bread fruit tree in which the flavonoids was expected to has a potent to decrease the blood glucose level. The aim of present study was to determine the activity of flavonoids compounds in decreasing the glucose level in vitro and it's correlation to the flavonoids content. Glucose level was measured in vitro according to Nelson Somogyi methods where $50 \%$ decrease of glucose level was set as a standard. Extract was prepared by gradual maceration methods consecutively using polar ( $n$-hexane), semi polar (ethyl acetate) dan polar (methanol) solvents. Flavonoids content was determined using spectrophotometer at wavelength $430 \mathrm{~nm}$ using sodium acetate and aluminum chloride as a reagents. Data from present results revealed that the total flavonoids content from total ethyl acetate and methanol extracts were respectively $0.5554 \%$ and $0.3727 \%$ of sample weight. The 50\% decrease of glucose level occurred at addition of $36.1114 \mathrm{ppm}$
\end{abstract}


ethyl acetate and 39.448 ppm ekstrak metanol. The present results also indicate the significant correlation between the total flavonoids content and the decrease of glucose level.

Key words: Diabetes mellitus, glucose level, flavonoid, bread fruit, Artocarpus altilis

\section{PENDAHULUAN}

kencing

Diabetes mellitus atau penyakit metabolik yang disebabkan oleh banyak faktor seperti kurangnya insulin atau ketidakmampuan tubuh untuk memanfaatkan insulin (insulin resistance), dengan simtoma berupa hiperglikemia kro nis dan gangguan metabolisme karbohidrat, lemak dan prote in, sebagai akibat defisiensi sekresi hormon insulin, aktivitas insulin, atau keduanya (Kitabchi et al., 2009). Diabetes mellitus mengakibatkan sindrom metabolik yang ditandai dengan peningkatan kadar glukosa dalam darah atau hiperglikemia disertai abnormalitas lipid, karbohidrat, protein serta peningkatan resiko komplikasi penyakit pembuluh darah; mikrovaskular, makrovaskular dan neuropati (Azrifitria dan Awalia, 2013). Diabetes terbagi dalam diabetes tipe 1 yang disebabkan oleh rusaknya pankreas yang berakibat turunnya produksi insulin dan diabetes tipe 2 yang disebabkan resistensi insulin terhadap glukosa. Pilihan terapi untuk semua diabetes tipe 1 hanya satu yaitu pemberian insulin secara intravena atau intramuscular jika diperlukan sedangkan diabetes tipe 2 dapat diobati dengan obatobat hipoglikemik oral golongan sulfonilurea, meglitinid, biguanid, penghambat $\alpha$-glukosidase dan tiazolidindion (Laakso, 2010).

Pohon sukun (Artocarpus altilis (Park.) Fosberg.) adalah pohon yang mudah dijumpai diberbagai daerah di Indonesia. Masyarakat di beberapa daerah biasa memanfaatkan daun dan kulit pohon sukun sebagai bahan ramuan obat untuk mengobati macam-macam penyakit seperti penyakit liver, hepatitis, sakit gigi, gatal- gatal, pembengkakan limpa, jantung, asam urat dan ginjal (Anonim, 2012). Hasil penelitian Yuswantina (2010) menunjukan bahwa ekstrak etanol daun sukun dapat meningkatkan imun non spesifik pada mencit dan memiliki aktivitas penangkap radikal bebas.

Menurut Suryanto dan Wehantouw (2009), daun sukun kaya akan senyawa fenolik, flavonid dan tanin. Zat-zat tersebut mampu mengatasi peradangan, menurunkan kolesterol, mengobati penyakit hati, inflamasi, jantung, ginjal dan pembuluh darah (Maharani et al., 2009). Flavonoid diduga merupakan senyawa yang bertanggung jawab dalam aktivitas penurunan kadar glukosa daun sukun. Flavonoid alam ditemukan dalam bentuk glikosida, yaitu suatu bentuk kombinasi antara gula dan alkohol. Senyawa ini merupakan kandungan khas tumbuhan hijau, terdapat pada semua bagian tumbuhan termasuk daun, akar, kulit kayu, tepung sari, nektar, bunga, buah, dan biji. Menurut perkiraan, kira-kira 2\% dari seluruh karbon yang difotosintesis oleh tumbuhan (atau kira-kira 1x $10^{9}$ ton/tahun) diubah menjadi flavonoid (Markham, 1988).

Menurut Kurniawan (2013) ekstrak etanol dan isolat flavonoid dari daun sukun dapat menurunkan kadar glukosa secara in vitro dengan metode Nelson Somogyi, sedangkan aktivitas penurunan kadar glukosa dari eks trak pelarut lain belum diketahui. Berdasarkan hal tersebut, maka tujuan dari penelitian ini adalah untuk mengetahui aktivitas penurunan kadar glukosa ekstrak daun sukun dengan pelarut metanol dan etil asetat, serta mempelajari bagaimana korelasi antara kadar flavonoid dengan aktivitas penurunan kadar glukosa dari ekstrak daun sukun secara in vitro. 


\section{METODE PENELITIAN \\ Waktu dan Tempat}

Penelitian ini dilaksanakan pada bulan April sampai Desember 2015, bertempat di Laboratorium Farmasi Fakultas Matematika dan Ilmu Pengetahuan Alam Universitas Pakuan, Bogor.

\section{Bahan dan Alat}

Bahan-bahan yang digunakan pada penelitian ini adalah daun sukun (Artocarpus altilis , daun sukun (Artocarpus altilis) yang diperoleh dari kebun wisata ilmiah di Balai Penelitian Tanaman Obat dan Aromatik (Balittro) Cimanggu-Bogor dan dideterminasi di Herbarium Bogoriense Bidang Botani Pusat Penelitian Biologi-LIPI, akuades, metanol, etil asetat, n-heksan, baku Dglukosa, reagen Nelson-Somogyi, reagen arsenomolibdat, kloroform, ammonia, pereaksi (Dragendorff, Mayer \& Wagner), serbuk magnesium $(\mathrm{Mg})$, asam klorida ( $\mathrm{HCl})$ pekat, amil alkohol, asam asetat anhidrat, asam sulfat $\left(\mathrm{H}_{2} \mathrm{SO}_{4}\right)$ pekat dan besi(III) klorida $\left(\mathrm{FeCl}_{3}\right) 1 \%$.
Alat-alat yang digunakan dalam penelitian ini adalah rotary evaporator, corong pisah, peralatan gelas lainnya dan spektrofotometer UV-Vis.

\section{Metode Penelitian \\ Pembuatan Serbuk Simplisia}

Daun sukun dibersihkan dari pengotor yang menempel kemudian dicuci bersih dan dikeringkan dengan oven sampai beratnya konstan kemudian digiling dan diayak.

\section{Penetapan Kadar Air}

Prosedur penentuan kadar air simplisia dilakukan dengan menggunakan alat moisture balance.

\section{Penetapan Kadar Abu}

Sebanyak 2 g serbuk simplisia dimasukkan kedalam krus silikat yang telah ditimbang dan dipijarkan. Krus kemudian dipijarkan perlahan-lahan hingga arang habis, didinginkan dan ditimbang. Kadar abu dihitung dengan menggunakan persamaan (1) (DepKes RI, 2000).

Kadar abu $(\%)=\frac{(\text { bobot krus }+ \text { abu simplisia })-\text { bobot krus kosong }}{\text { Bobot sampel serbuk simplisia }} \times 100 \%$

\section{Ekstraksi Simplisia}

Ekstraksi dilakukan dengan metode maserasi bertingkat menggunakan pelarut dengan kepolaran meningkat yaitu nheksana, etilasetat, dan metanol. Metode maserasi merupakan metode pemisahan senyawa yang dilakukan dengan cara merendam serbuk simplisia dalam larutan penyari metode tanpa pemanasan. Keuntungan utama dari ekstraksi ini adalah caranya yang mudah dan dapat mencegah terjadinya kerusakan atau penguraian komponen bahan alam yang tidak tahan panas (Heinrich et al., 2005).

Sebanyak 500 gram serbuk simplisia dimaserasi menggunakan masing-masing 5 liter pelarut (1:10) secara bertahap. Tahap pertama serbuk simplisia dimaserasi dengan 75 bagian pelarut n-heksan (3500 $\mathrm{mL})$ selama 24 jam sambil sesekali dikocok, setelah 24 jam filtrat dipisahkan, residu dimaserasi dengan 25 bagian (1500 mL) n-heksan selama 24 jam sambil sesekali dikocok. Setelah maserasi dengan n-heksana selesai, simplisia dikeringkan kemudian dimaserasi etil asetat dilanjutkan maserasi dengan metanol menggunakan prosedur yang sama. Filtrat yang diperoleh dari masing-masing pelarut disimpan dalam wadah tertutup, di tempat sejuk dan terlindung dari cahaya selama 24 jam, kemudian filtrat dipekatkan dalam rotary evaporator sampai didapatkan ekstrak 
kental. Rendemen dihitung dengan menggunakan persamaan (2).

Ekstrak kental etilasetat dan metanol dari daun sukun yang didapat kemudian digunakan dalam tahap uji selanjutnya yaitu uji fitokimia, uji penurunan kadar glukosa secara in vitro dan uji kadar flavonoid total.

Rendemen ekstrak $=\frac{\text { Berat ekstrak yang diperoleh }}{\text { Berat awal daun }} \times 100 \%$

\section{Analisis Fitokimia}

Analisis fitokimia dilakukan untuk mengetahui senyawa-senyawa yang terkandung dalam ekstrak. Uji Fitokimia pada ekstrak meliputi identifikasi saponin, tanin, flavonoid dan alkaloid secara kualitatif.

\section{Pembuatan Larutan Baku Glukosa 80 ppm}

Sebanyak 50 mg D-glukosa anhidrat dilarutkan dalam $50 \mathrm{~mL}$ akuades sehingga didapatkan konsentrasi 1000 ppm. Sebanyak $8,0 \mathrm{~mL}$ dari larutan tersebut dipipet dan dimasukkan ke dalam labu takar $100 \mathrm{~mL}$ kemudian ditambahkan akuades sampai tanda batas dan dihomogenkan sehingga diperoleh larutan standar D-glukosa 80 ppm.

\section{Pembuatan Pereaksi Nelson Somogyi}

a. Larutan Nelson A

Dilarutkan 12,5 g natrium karbonat anhidrat, 12,5 g kalium natrium tatrat, $10 \mathrm{~g}$ natrium bikarbonat, dan $100 \mathrm{~g}$ natrium sulfat anhidrat dalam $350 \mathrm{ml}$ akuadest. Kemudian diencerkan sampai $500 \mathrm{ml}$.

b. Larutan Nelson B

Dilarutkan 7,5 g tembaga (II) sulfat penta hidrat $\left(\mathrm{CuSO}_{4} 5 \mathrm{H}_{2} \mathrm{O}\right)$ dalam 50 $\mathrm{ml}$ akuades dan ditambahkan 1 tetes asam sulfat (pekat).

c. Pereaksi Nelson dibuat dengan cara mencampurkan $25 \mathrm{ml}$ bagian larutan Nelson A dan $1 \mathrm{~mL}$ bagian larutan Nelson B. Pencampuran dilakukan pada setiap hari akan digunakan.

\section{Pembuatan Larutan Arsenomolybdat.}

Sebanyak $25 \mathrm{~g}$ ammonium molybdat dilarutkan dalam $450 \mathrm{ml}$ akuadest dan ditambahkan $25 \mathrm{~mL}$ asam sulfat pekat. Pada tempat lain dilarutkan $3 \mathrm{~g}$ natrium arsenat hepta hidrat $\left(\mathrm{Na}_{2} \mathrm{H}_{2} \mathrm{SO}_{4} .7 \quad \mathrm{H}_{2} \mathrm{O}\right)$ dalam $25 \mathrm{~mL}$ akuades. Larutan kedua dituangkan kedalam larutan yang pertama, disimpan dalam botol berwarna cokelat, Selanjutnya diinkubasi pada suhu $37^{0} \mathrm{C}$ selama 24 jam (hingga larutan berwarna kuning).

\section{Penentuan Panjang Gelombang Maksimum Glukosa}

Dipipet $5 \mathrm{~mL}$ larutan baku glukosa 80 ppm dimasukkan ke dalam labu ukur 10 $\mathrm{mL}$, lalu diencerkan sampai batas. Dipipet $1 \mathrm{~mL}$ dari larutan tersebut dimasukkan ke dalam tabung reaksi lalu ditambahkan 1 $\mathrm{mL}$ reagen nelson dan ditutup dengan kapas kemudian dipanaskan di atas air mendidih selama 10 menit. Larutan didinginkan selama 5 menit kemudian dipindahkan ke dalam labu ukur $10 \mathrm{~mL}$, ditambahkan $1 \mathrm{~mL}$ reagen arsenomolibdat kemudian diencerkan dengan akuades sampai batas, dikocok dan didiamkan selama waktu inkubasi. Hasilnya dibaca dengan spektrofotometer UV-Vis pada panjang gelombang 700-780 $\mathrm{nm}$.

\section{Penentuan Waktu Inkubasi Optimum Glukosa}

Dipipet $5 \mathrm{~mL}$ larutan baku glukosa 80 ppm dimasukkan ke dalam labu ukur 10 $\mathrm{mL}$, lalu diencerkan sampai batas. Dipipet $1 \mathrm{~mL}$ dari larutan tersebut ke dalam tabung reaksi lalu ditambahkan $1 \mathrm{~mL}$ reagen nelson, ditutup dengan kapas kemudian dipanaskan di atas air mendidih selama 10 menit. Larutan didinginkan selama 5 menit 
kemudian dipindahkan kendalam labu ukur $10 \mathrm{~mL}$ kemudian ditambahkan $1 \mathrm{~mL}$ reagen arsenomolibdat kemudian diencerkan dengan akuades sampai batas dan dikocok. Serapan diukur pada panjang gelombang maksimum pada $5,10,15,20$, 25 dan menit, sehingga didapat waktu optimum yang stabil.

\section{Penentuan Kadar Glukosa}

Metode Nelson Somogyi digunakan untuk menguji kadar glukosa pada penelitian ini karena bahan-bahan yang digunakan lebih mudah diperoleh dan tidak memerlukan perlakuan khusus pada saat pengujian. Kekurangan dari metode ini adalah kurang spesifik untuk mengukur kadar glukosa karena metode ini dapat juga mengikat gula pereduksi lain yaitu senyawa gula yang memiliki gugus aldehid dan keton.

Ekstrak metanol dan ekstrak etil asetat daun sukun masing-masing dibuat seri konsentrasi 60, 80, 100, 120, 140, 160 dan 180 ppm. Dari masing-masing konsentrasi dipipet $5 \mathrm{~mL}$ ke dalam tabung reaksi, ditambahkan $5 \mathrm{~mL}$ baku glukosa dengan konsentrasi 80 ppm. Dari larutan tersebut dipipet $1 \mathrm{~mL}$ ke dalam tabung reaksi, ditambah $1 \mathrm{~mL}$ reagen nelson ditutup dengan kapas kemudian dipanaskan di atas air mendidih selama 10 menit. Larutan didinginkan selama 5 menit lalu dipindahkan ke dalam labu ukur 10 $\mathrm{mL}$, ditambah $1 \mathrm{~mL}$ reagen arsenomolibdat kemudian diencerkan dengan akuades sampai tanda batas, dikocok dan didiamkan selama waktu inkubasi. Hasilnya dibaca dengan spektrofotometer $\mathrm{UV}-\mathrm{Vis}$ pada panjang gelombang maksimal.

Absorbansi yang diperoleh dari pengukuran sampel ekstrak etanol dan isolat flavonoid daun sukun dikurangi dengan absorbansi blanko. Nilai absorban kemudian dimasukkan ke dalam regresi linier deret baku untuk mengetahui kadar glukosa. Selanjutnya dihitung persentase penurunan kadar glukosa menggunakan persamaan (3).

$\%$ Penurunan Kadar Glukosa $=\frac{\text { kadar baku-kadar sampel }}{\text { kadar baku }} \times 100 \%$

\section{Penentuan Kadar Flavonoid Ekstrak} Kadar flavonoid ekstrak daun sukun dihitung berdasarkan standar senyawa kuersetin. Sebelum kadar flavonoid diukur, ditentukan terlebih dulu kurva standar kuersetin. Kurva kalibrasi kuersetin diperoleh dengan melakukan pembuatan deret konsentrasi kuersetin 2, 4, 6, 8, 10 ppm dan melakukan pengukuran absorbansi dari deret sehingga didpatkan persamaan linieritas antara absorbansi dengan konsentrasi. Setelah didapat kurva standar kuersetin kadar flavonoid ekstrak daun sukun diukur dengan cara $50 \mathrm{mg}$ ekstrak daun sukun dilarutkan dengan metanol sampai $50 \mathrm{~mL}$. Dipipet sebanyak $10 \mathrm{~mL}$ dari masing-masing ekstrak ke dalam labu ukur $50 \mathrm{~mL}$ lalu ditambahkan akuades kira-kira $20 \mathrm{~mL}, 1 \mathrm{~mL}$ almunium klorida $10 \%, 1 \mathrm{~mL}$ natrium asetat $1 \mathrm{M}$ dan air suling sampai batas. Dikocok homogen lalu dibiarkan selama waktu optimum, lalu serapan diukur pada panjang gelombang maksimal. Absorban yang dihasilkan dimasukkan kedalam persamaan regresi dari kurva standar kuersetin. Kemudian dihitung flavonoid total dengan menggunakan persamaan (4).

$\%$ kadar flavonoid $=\frac{\mathrm{ppm} \times \text { volume } \times \mathrm{fp} \times 10^{-6}}{\text { gram bobot simlpisia }} \times 100 \%$

\section{HASIL PENELITIAN}


Karakteristik Serbuk Simplisia Daun Sukun

Serbuk simplisia daun sukun yang diperoleh memiliki warna hijau kecoklatan dengan aroma khas dan memiliki rasa agak pahit. Serbuk simplisia daun sukun dapat dilihat pada Gambar 1. Rendemen simplisia yang diperoleh sebesar 17,23\%.

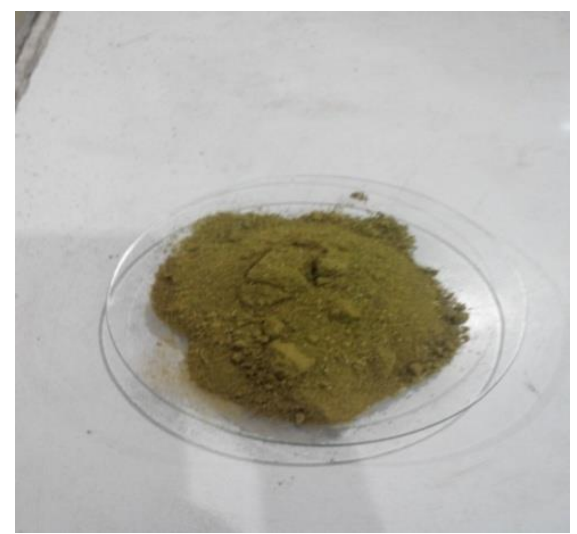

Gambar 1. Serbuk Simplisia Daun Sukun

Kadar air serbuk simplisia yang diperoleh sebesar 4,47\%. Hasil ini memenuhi syarat dari DepKes RI (1979) yang menyatakan bahwa syarat kadar air simplisisa secara umum tidak lebih dari 5\%. Kadar air merupakan salah satu parameter penting dalam standarisasi suatu simplisia karena dengan kadar air yang terlalu tinggi akan memungkinkan pertumbuhan mikroba yang akan mempengaruhi mutu dari simplisia tersebut.

Kadar abu yang terdapat dalam simplisia adalah sebesar 9,6825\%, sesuai dengan standar maksimal kadar abu total dalam simplisia menurut DepKes RI (2000) tidak lebih dari 15\%. Kadar abu simplisia perlu ditentukan untuk mengetahui atau mengidentifikasi banyaknya zat anorganik dan mineral yang biasa ditemukan dalam serbuk simplisia. Kadar abu yang diperoleh dari suatu simplisia menunjukkan banyaknya kandungan unsur-unsur logam dalam simplisia.

\section{Hasil Ekstraksi Daun Sukun}

Serbuk simplisia yang digunakan dalam maserasi ini sebanyak 500 gram. Hasil rendemen ekstrak etil asetat dan metanol yang diperoleh dapat dilihat pada Tabel 1.

Rendemen yang dihasilkan dari ekstrak etil asetat dan ekstrak metanol sebesar 5,55 \% dan 9,575\%. Rendemen ekstrak menunjukkan banyaknya jumlah senyawa aktif yang terekstraksi oleh pelarut yang digunakan dan berdasarkan hasil rendemen senyawa aktif lebih banyak terdapat pada ekstrak metanol, dengan demikian maka metanol merupakan pelarut yang paling baik untuk mengekstraksi senyawa aktif dalam simplisia daun sukun.

\section{Hasil Uji Fitokimia Ekstrak Daun Sukun}

Hasil uji fitokimia dari ekstrak etil asetat dan metanol daun sukun dapat dilihat pada Tabel 2.

Hasil uji fitokimia ini sejalan dengan hasil-hasil penelitian sebelumnya yang menunjukan bahwa daun sukun kaya akan senyawa-senyawa fenolik terutama golongan flavonid Selain senyawasenyawa flavonoid, daun sukun juga terbukti mengandung senyawa metabolit sekunder lainnya seperti tanin, saponin dan alkaloid (Riasari et al., 2015). 
Tabel 1. Rendemen Ekstrak Etil Asetat dan Metanol

\begin{tabular}{lccc}
\hline Pelarut & $\begin{array}{c}\text { Bobot simplisia } \\
\text { (gram) }\end{array}$ & $\begin{array}{c}\text { Bobot Ekstrak } \\
\text { (gram) }\end{array}$ & $\begin{array}{c}\text { Rendemen ekstrak } \\
\text { kental daun sukun }\end{array}$ \\
\hline Etil Asetat & 500 & 27,75 & $5,55 \%$ \\
Metanol & 500 & 48,85 & $9,57 \%$ \\
\hline
\end{tabular}

Tabel 2. Hasil Uji Fitokimia Ekstrak Daun Sukun

\begin{tabular}{lrrrr}
\hline \multirow{2}{*}{ Sampel } & \multicolumn{4}{c}{ Golongan Senyawa Kimia } \\
\cline { 2 - 5 } & Alkaloid & Flavonoid & Saponin & Tanin \\
\hline Etil asetat & + & + & + & + \\
Metanol & + & + & + & + \\
\hline
\end{tabular}

Keterangan: (+) terdeteksi, (-) tidak terdeteksi

\section{Waktu Inkubasi Optimum}

Penentuan waktu inkubasi dilakukan untuk mengetaui waktu yang dibutuhkan suatu zat agar dapat bereaksi dengan maksimal dan stabil. Waktu inkubasi optimum glukosa didapatkan pada menit ke 25 seperti terlihat pada Gambar 2.

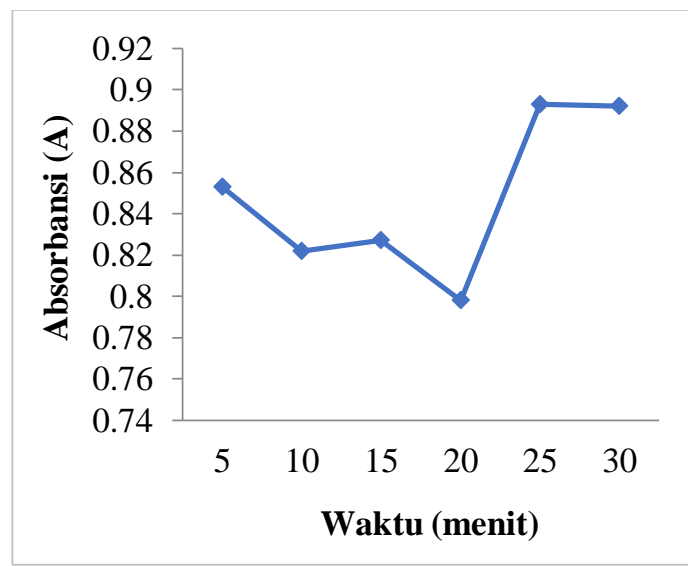

Gambar 2. Waktu Inkubasi Optimum Glukosa

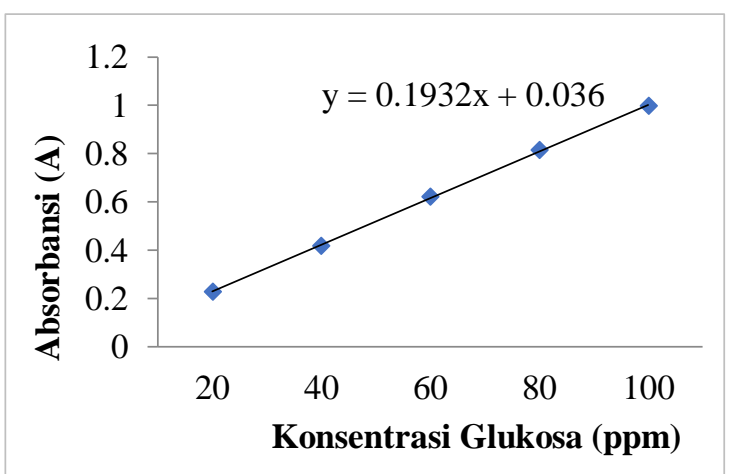

Gambar 3. Kurva Kalibrasi Larutan Standar Glukosa
Persamaan linier yang didapat dari kurva kalibrasi adalah $\mathrm{y}=0,01932 \mathrm{x}+0,036$ dengan nilai koefisien relasi $\mathrm{R}^{2}=0,9998$. Nilai $R^{2}$ menunjukkan adanya korelasi antara absorbansi dengan konsentrasi. Persamaan kurva kalibrasi standar glukosa dapat dilihat pada Gambar 3.

\section{Penurunan Kadar Glukosa}

Pengujian kadar glukosa dilakukan untuk mengetahui aktivitas ekstrak etil asetat dan ekstrak metanol daun sukun terhadap penurunan kadar glukosa. Penghitungan dilakukan menggunakan persamaan linier dari kurva kalibrasi kadar glukosa yang dapat dilihat pada Gambar 4 dan Gambar 5. Persentase penurunan kadar glukosa dapat dilihat pada Tabel 3.

Pengujian aktivitas penurunan kadar glukosa menunjukkan adanya pengaruh penambahan ekstrak kental etil asetat dan metanol terhadap kadar baku glukosa. Ekstrak etil asetat dan metanol daun sukun menunjukkan kemampuan penurunan kadar glukosa yang berbeda. Ekstrak metanol daun sukun mampu menurunkan 50\% kadar glukosa baku pada konsentrasi 39,448 ppm sedangkan ekstrak etil asetat daun sukun pada konsentrasi 36,1114 ppm. Nilai ini menunjukkan bahwa ekstrak etil asetat lebih efektif menurunkan 50\% kadar baku glukosa. Semakin kecil konsentrasi yang diperlukan untuk menurunkan 50\% kadar glukosa 
maka semakin besar aktivitas penurunan kadar glukosa.

Penurunan kadar glukosa setelah ekstrak etil asetat dan ekstrak metanol ditambahkan kemungkinan disebabkan larutan glukosa akan membentuk kompleks glukosa dengan flavonoid. Gugus $\mathrm{OH}$ yang terletak dinomor 3' dan 4' pada flavonoid diduga mampu mengikat glukosa yang membuat kadar glukosa yang ada pada larutan baku akan berkurang. Sisa glukosa yang tidak terikat oleh flavonoid akan bereaksi dengan reagen Nelson dan membentuk endapan merah bata kemudian penambahan reagen arsenomolibdat menghasilkan molibdine yang berwarna biru kehijauan, lalu diukur serapannya dengan spektrofotometer UV-Vis (Kurniawan, 2013).

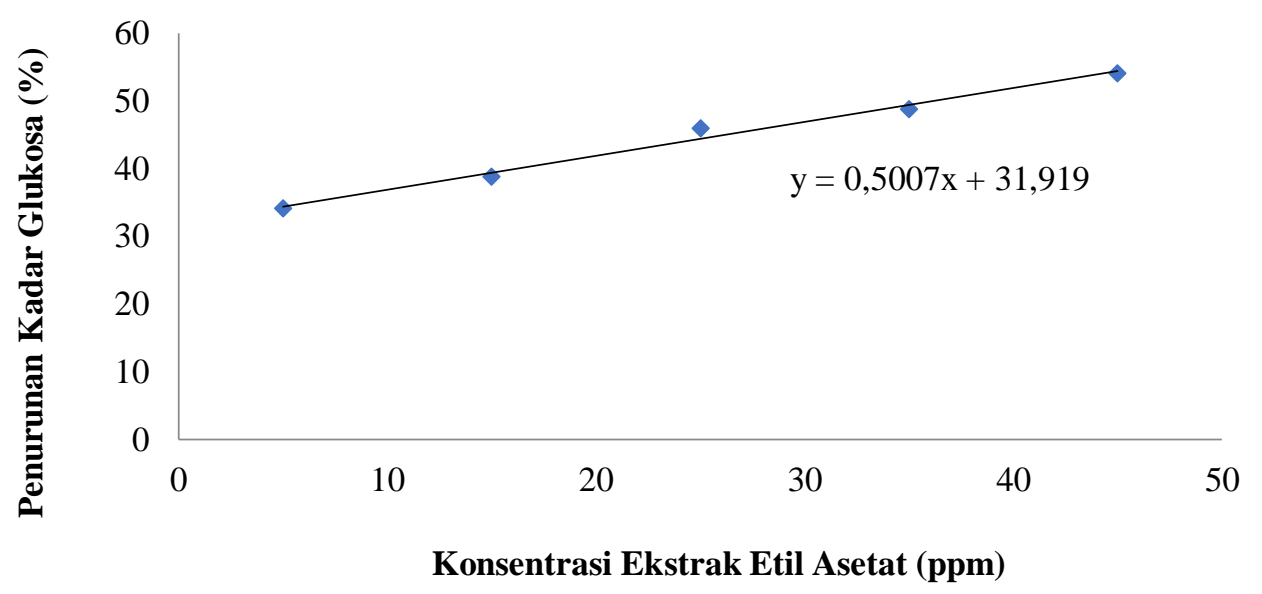

Gambar 4. Grafik Penurunan Kadar Glukosa Setelah Pemberian Ekstrak Etil Asetat Daun Sukun

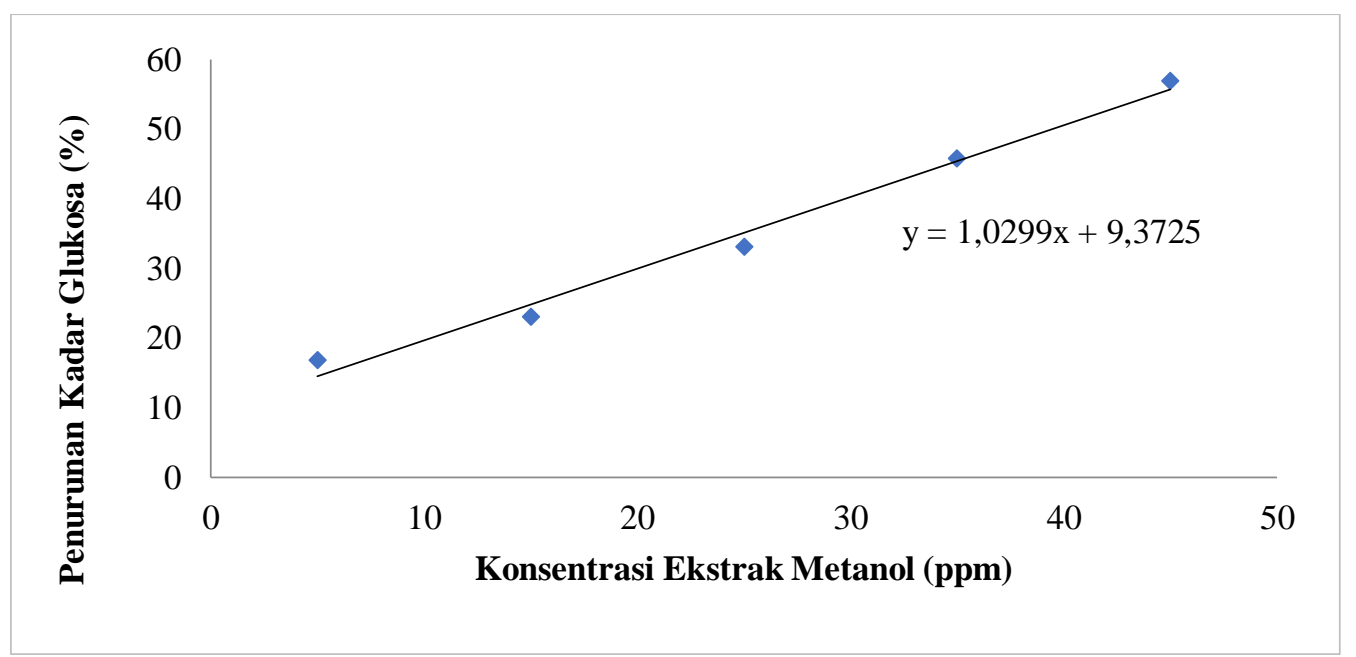

Gambar 5. Grafik Penurunan Kadar Glukosa Setelah Pemberian Ekstrak Metanol Daun Sukun 
Tabel 3. Persentase Penurunan Kadar Glukosa Ekstrak Etil Asetat dan Metanol Daun Sukun

\begin{tabular}{ccr}
\hline \multirow{2}{*}{$\begin{array}{c}\text { Konsentrasi } \\
(\text { ppm })\end{array}$} & \multicolumn{2}{c}{ Penurunan Kadar Glukosa } \\
\cline { 2 - 3 } & Ekstrak Etil Asetat & Ekstrak Metanol \\
\hline 5 & $34,1356 \%$ & $16,7962 \%$ \\
10 & $37,1125 \%$ & $21,9720 \%$ \\
15 & $38,9235 \%$ & $23,0072 \%$ \\
20 & $43,5817 \%$ & $31,9360 \%$ \\
25 & $46,0405 \%$ & $33,1005 \%$ \\
30 & $47,4637 \%$ & $38,9235 \%$ \\
35 & $48,8875 \%$ & $45,7817 \%$ \\
40 & $51,3457 \%$ & $53,4162 \%$ \\
45 & $54,1927 \%$ & $56,9100 \%$ \\
50 & $56,5217 \%$ & $57,2982 \%$ \\
\hline
\end{tabular}

\section{Kadar Flavonoid Total Ekstrak Daun} Sukun

Prinsip penetapan flavonoid dengan metode ini adalah pembentukan kompleks antara $\mathrm{AlCl}_{3}$ dengan gugus keto pada atom C-4 dan juga dengan gugus hidroksi pada atom $\mathrm{C}-3$ atau $\mathrm{C}-4$ yang bertetangga dari flavon dan flavonol. Penggunaan kuersetin sebagai pembanding karena kuersetin merupakan flavonoid golongan flavonol yang mempunyai gugus hidroksi pada C-4 dan memiliki gugus hidroksi pada atom $\mathrm{C}$ 3 atau C-5 yang bertetangga dari flavon dan flavonol (Chang et al., 2002). Panjang gelombang maksimum yang dihasilkan dari pengukuran kuersetin adalah $430 \mathrm{~nm}$. Panjang gelombang maksimal yang dihasilkan mendekati dengan literatur, menurut Selawa (2013) panjang gelombang maksimal dari kuersetin 415 nm.

Optimasi waktu inkubasi dilakukan pada beberapa titik waktu yaitu $5,10,15$, 20, 25 dan 30 menit. Optimasi waktu inkubasi dilakukan untuk mengetahui waktu penyimpanan yang memberikan serapan stabil dan juga untuk mengetahui waktu yang dibutuhkan suatu zat agar dapat bereaksi dengan maksimal. Hasil pengujian menunjukkan bahwa waktu inkubasi yang optimum didapat pada waktu 20 menit. Grafik waktu inkubasi kuersetin dapat dilihat pada Gambar 6.

Persamaan linier yang didapat $\mathrm{y}=$ $0,08485 \mathrm{x}+0,1075$ dengan nilai koefisien korelasi $\mathrm{r}=0,9998$ menunjukkan bahwa ada korelasi antara nilai absorbansi dengan konsentrasi. Kurva kalibrasi kuersetin dapat dilihat pada Gambar 7.

Dari hasil penghitungan kadar flavonoid menggunakan kurva kalibrasi didapat rata-rata kadar flavonoid total ekstrak etil asetat daun sukun sebesar 0,5554\% dan kadar flavonoid total ekstrak metanol daun sukun sebesar 0,3727\%. Kadar flavonoid ekstrak etil asetat $65 \%$ lebih tinggi dibandingkan dengan kadar flavonoid ekstrak metanol.

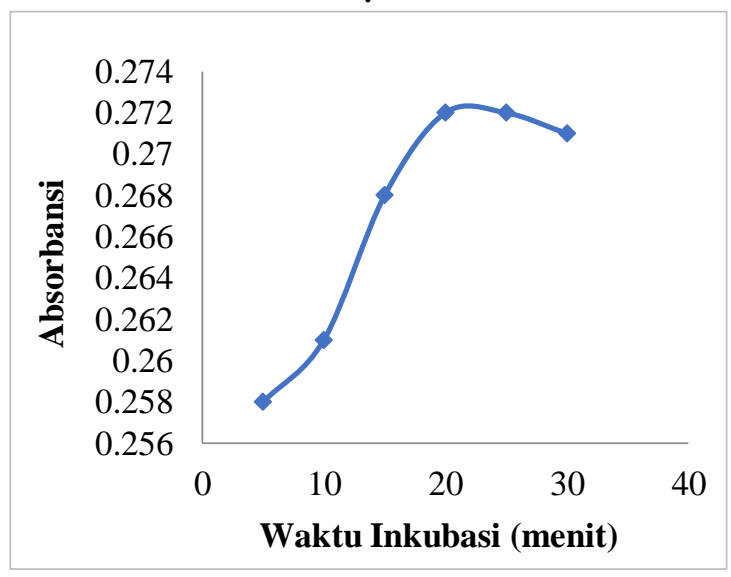

Gambar 6: Grafik Waktu Inkubasi Kuersetin 


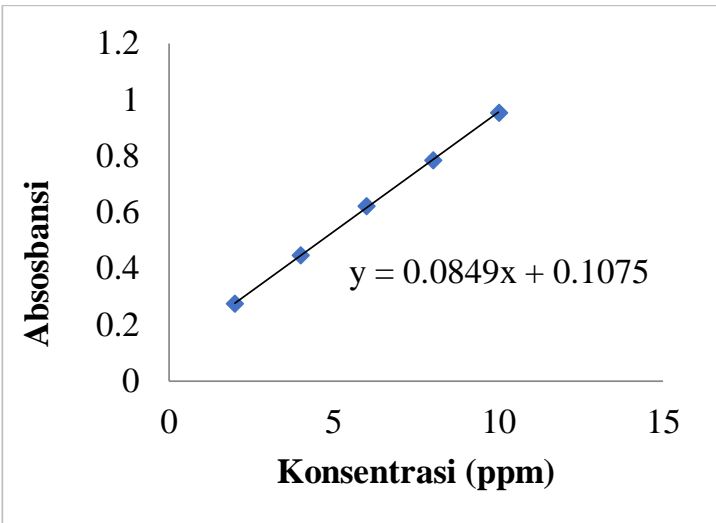

Gambar 7. Kurva Kalibrasi Kuersetin

Korelasi Antara Kadar Flavonoid Total dan Penurunan Kadar Glukosa

Analisis korelasi antara kadar flavonoid total dan penurunan kadar glukosa dilakukan dengan metode pearson correlation menggunakan aplikasi SPSS. Hasil uji korelasi dapat dilihat pada Tabel 4.

Nilai korelasi antara persentase penurunan kadar glukosa ekstrak etil asetat daun sukun dengan kadar flavonoid total ekstrak etil asetat adalah 0,918 sedangkan nilai korelasi antara persentase penurunan kadar glukosa ekstrak metanol dengan kadar flavonoid total dari ekstrak metanol adalah 0,987 . Nilai korelasi keduanya mendekati angka 1 sehingga dapat dinyatakan bahwa terdapat korelasi atau hubungan yang nyata antara kadar flavonoid dengan aktivitas penurunan kadar glukosa secara invitro dengan metode Nelson Somogyi. Namun nilai korelasi yang lebih baik diantara kedua ekstrak ditunjukkkan oleh ekstrak metanol karena nilai korelasinya lebih mendekati angka 1. Semakin besar kadar flavonoid maka nilai penurunan 50\% kadar glukosa akan semakin kecil yang berarti aktivitas penurunan kadar glukosa semakin baik. Hasil penelitian ini menunjukkan bahwa ekstrak etil asetat dan metanol daun sukun dapat menurunkan kadar glukosa secara in vitro, sejalan dengan penelitian Mu'nisa (2012) yang telah membuktikan bahwa ektrak daun sukun dapat menurunkan kadar glukosa dan malondialdehida pada mencit yang diinduksi aloksan.

Tabel 4. Hasil Analisis Korelasi.

\begin{tabular}{ll}
\multicolumn{1}{c}{ Variabel } & Nilai Korelasi \\
$(\%$ Penurunan Kadar Glukosa $\sim$ Flavonoid Total $)$ & \\
\hline Etil Asetat & 0,918 \\
Metanol & 0,987 \\
\hline
\end{tabular}




\section{KESIMPULAN DAN SARAN \\ Kesimpulan}

Dari hsil-hasil yang didapatkan dapat disimpulkan bahwa:

1. Ekstrak etil asetat menurunkan $50 \%$ kadar glukosa pada konsentrasi 36,1114 ppm dan ekstrak metanol pada konsentrasi 39,448 ppm.

2. Kadar flavonoid ekstrak etil asetat adalah 0,5554\% dari berat sampel dan kadar flavonoid ekstrak metanol adalah $0,3727 \%$ dari berat sampel.

3. Terdapat korelasi antara kadar flavonoid pada ekstrak etil asetat dan metanol daun sukun dan persentase penurunan kadar glukosa secara in vitro. Semakin tinggi kadar flavonoid maka semakin besar aktivitas penurunan kadar glukosa.

\section{Saran}

Perlu dilakukan penelitian lebih lanjut untuk mengetahui aktivitas antidiabetes ekstrak etil asetat dan metanol daun sukun secara in vivo dengan metode penghambatan enzim $\alpha$-glukosidase dan penentuan kadar flavonoid dengan metode 2,4-dinitrofenilfidrazin (DNPH) dengan pembanding naringenin.

\section{DAFTAR PUSTAKA}

Anonim. 2012. Kandungan dan Manfaat Daun Sukun. Diunduh dari http://daunsukun.com. [15 November 2014].

Chang, C.C., M.H. Yang, H.M. Wen dan J.C. Chernn. 2002. Estimation of Total Flavonoid Content in Propolis by Two Complementary Colorimetric Methods, Journal of Food and Drug Analysis. 10 (3): 178- 182.

DepKes RI. 2000. Parameter Standar Umum Ekstrak Tumbuhan Obat. Jakarta.

Heinrich M., J. Barnes, S. Gibbons dan E.M. Williamson. 2005. Farmakognosi dan
Fitoterapi. Penerbit Buku Kedokteran EGC. Jakarta

Kitabchi, A.E., G.E. Umpierrez, J.M. Miles dan J.N. Fisher. 2009. Hyperglycemic crises in adult patients with diabetes. Diabetes Care. 32 (7): 1335-1343.

Kurniawan, A.N.R. 2013. Pengaruh Ekstrak Etanol dan Isolat Flavonoid Daun Sukun (Artocarpus altilis (Park.) Fosberg) Terhadap Aktivitas Penurunan Kadar Glukosa Secara In Vitro. Artikel. Sekolah Tinggi Ilmu Farmasi "Yayasan Pharmasi". Semarang.

Laakso, M. 2010. Cardiovaskular dissease in type 2 diabetes from population to man to mechanisms. Diabetes Care. 33 (2): 442-449.

Maharani E.T.W., A.H. Mukaroma dan M.F. Farabi. 2009. Uji Fitokimia Daun Sukun Kering (Artocarpus altilis). Fakultas Ilmu Keperawatan dan Kesehatan Universitas Muhammadiyah. Semarang.

Markham K.R. 1988. Cara mengidentifikasi flavonoid. Diterjemahkan oleh Padmawinata. ITB, Bandung.

Mu'nisa, A. M., dan A. Farida. 2012. Uji Aktivitas Antioksidan Ekstrak Daun Sukun Terhadap Kadar Glukosa Darah dan Malondialdehid (MDA) pada Mencit (Mus musculus). Penelitian Disajikan (Oral) dalam Simposium Nasional Kimia Bahan Alam ke-XX. UIN, Jakarta.

Riasari H, M. Ulfah, D. Prayugo D and N.A Komariah. 2017. Antibacterial and antifungal activities of various bread fruit leaves (Artocarpus altilis (Parkinson) fosberg). Int $\mathrm{J}$ Pharm Sci Res. 8(3): 1066-1073.

Selawa, W., M.R.J. Runtuwene dan G. Citraningtyas. 2013. Kandungan Flavonoid dan Kapasitas Antioksidan Total Ekstrak Etanol Daun Binahong 
Fitofarmaka, Vol.6, No.2, Desember 2016 ISSN:2087-9164

(Anredera cordifolia (Ten.) Steenis. Jurnal Ilmiah Farmasi Pharmacon. 2

(1).

Suryanto, E. dan F. Wehantouw. 2009. Aktivitas Penangkap Radikal Bebas Dari Ekstrak Fenolik Daun Sukun (Artocarpus altilis F.). Chem. Prog. 2 (1): 1-7.

Tjay, T.H. dan K. Rahardja. 2007. Obat-Obat

Penting, Khasiat, Penggunaan dan Efek-efek Sampingnya. Edisi VI. Elex Media Komputindo: Jakarta.

Yuswantina, R., A.R. Erwiyani dan Prihati.

2013. Efek Imunomodulator Ekstrak Etanol

Daun Sukun (Artocarpus altilis (Park.)

Fosberg) Terhadap respon Imun Non Spesifik Pada mencit Jantan Galur BALB/C. Jurnal Farmasi dan Obat Alam. 2 (2): 